\title{
Land Resource Areas and Spatial Analysis of Potential Location of Bioenergy Crops Production in Mississippi
}

\author{
Yaw Adu Twumasi ${ }^{*}$, Edmund Chukwudi Merem², John Bosco Namwamba1, \\ Jacob Banafo Annan', Tomas Ayala-Silva ${ }^{3}$, Abena Boatemaa Asare-Ansah"1, Zhu Hua Ning1, \\ Judith Oppong1, Priscilla Mawuena Loh ${ }^{1}$, Diana Botchway Frimpong ${ }^{1}$, Faustina Owusu', \\ Janeth Ernest Mjema', Ronald Okwemba1, Olipa Simon Mwakimi4, Brilliant Mareme Petja5, \\ Caroline Olufunke Akinrinwoye ${ }^{1}$, Joyce McClendon-Peralta1, Hermeshia Jonee Mosby ${ }^{1}$ \\ ${ }^{1}$ Department of Urban Forestry and Natural Resources, Southern University and A\&M College, Baton Rouge, Louisiana, USA \\ ${ }^{2}$ Department of Urban and Regional Planning, Jackson State University, Jackson, Mississippi, USA \\ ${ }^{3}$ USDA-ARS Tropical Agriculture Research Station 2200 P.A., Mayaguez, Puerto Rico, USA \\ ${ }^{4}$ Institute of Resource Assessment, University of Dares Salam, Dares Salam, Tanzania \\ ${ }^{5}$ Water Research Commission (WRC) Private Bag X03, Gezina, South Africa \\ Email: *yaw_twumasi@subr.edu, *yaw.twumasi@gmail.com
}

How to cite this paper: Twumasi, Y.A., Merem, E.C., Namwamba, J.B., Annan, J.B., Ayala-Silva, T., Asare-Ansah, A.B., Ning, Z.H., Oppong, J., Loh, P.M., Frimpong, D.B., Owusu, F., Mjema, J.E., Okwemba, R., Mwakimi, O.S., Petja, B.M., Akinrinwoye, C.O., McClendon-Peralta, J. and Mosby, H.J. (2021) Land Resource Areas and Spatial Analysis of Potential Location of Bioenergy Crops Production in Mississippi. Journal of Sustainable Bioenergy Systems, 11, 187-214.

https://doi.org/10.4236/jsbs.2021.114013

Received: June 13, 2021

Accepted: October 15, 2021

Published: October 18, 2021

Copyright $\odot 2021$ by author(s) and Scientific Research Publishing Inc. This work is licensed under the Creative Commons Attribution International License (CC BY 4.0).

http://creativecommons.org/licenses/by/4.0/ (c) (i) Open Access

\begin{abstract}
Mississippi State is renowned for its land resource areas (LRA) and production of bioenergy crops which generate both agricultural and economic benefits. Agricultural commodities play a key role in economic growth, therefore the ability to produce more would enhance development. This paper offers an analysis of the production of bioenergy crops in Mississippi. Relative measures, time series graphs and descriptive statistics coupled with geographic information systems (GIS) mapping using ArcMap were employed to generate the outcome of this research. The outcome of the statistical analysis indicated that corn and soybeans were the most produced crops in Agricultural Districts 10 and 40. These districts produced more bioenergy crops than the other districts. GIS mapping results also showed that the potential area for bioenergy crops is in zone 131 of the Mississippi Land Resource Area (MLRA). This zone has an absolute advantage in the production of these crops which includes the diversity of biomass production such as corn, cotton, soybeans, wheat, rice, barley, grain sorghum, canola, camelina, algae, hardwoods, and softwood. The paper recommends a constant GIS mapping and land management systems for each agricultural district in Mississippi to enable researchers and farmers to determine the factors which contribute towards the increasing and decreasing trends in the production of
\end{abstract}


the bioenergy crops.

\section{Keywords}

Land Resource Areas, GIS, Bioenergy Crops, Descriptive Statistics, Mississippi

\section{Introduction}

The concept of bioenergy is defined by the Food and Agriculture Organization of the United Nations as all forms of energy extracted from biofuels [1]. Typologically, biofuels can be broken down into solid, liquid and gas. Based on origin, biofuels are subdivided into three categories: forest, agriculture and municipal waste. In the context of climate change, economic growth and energy security, bioenergy as a significant renewable energy from organic materials are becoming a progressively appealing energy alternative. On the flip side, with a growing world population as well as regional and global economies growing expeditiously, the ordinary fuel-based energy alone is not on the horizon to fork out indispensable and abundant underpinnings to the operation of modern economies due to its finite supply, high or unstable prices and agitations about national fuel autonomy [2].

According to the International Energy Agency [3], bioenergy presently provides approximately $10 \%$ of global supplies and accounts for about $80 \%$ of the energy obtained from renewable sources. Fuel made from plants such as wheat, corn, soybeans, and sugarcane has gained worldwide attention in recent years. Fuels from these plants have been identified as being among the cleanest energy sources due to the minimal impact the products of their oxidation have on the environment. The conceptualization of bioenergy crop production is becoming a limelight in the scientific community attributable to its sustainability and environmentally-sound nature [4]. Bioenergy crops are energy sources that have a positive impact on the environment since the combustion of their fuel products emits fewer greenhouse gases than fossil fuels and the crops can be regrown, hence renewable in nature. Bioenergy crops could help replenish soil carbon through the addition of biochar, a biofuel into soil as an amendment. Through this practice, carbon is extracted from the atmosphere aby stored in soil, since the carbon in biomass was extracted from the atmosphere by photosynthesis. The crops include distinct plants which are grown and nourished at lower costs for biofuel production. Cushion et al. [5] write that, similarly, in the preceding decade, Bioenergy crop production has been embraced by the international community for decades. The unreliability in supply of oil by oil producing countries, demands for alternative energy sources by the energy consumers countries and hence, biofuels serve as cushions during such occurrences. The need to reduce the impact of energy use on climate and provide an environmentally sustainable energy source, while stimulating rural development has played a major role in the shift to promoting the production of bioenergy crops. 
Yadav et al. [6] classified bioenergy crops into first, second and third generation bioenergy crops, dedicated energy crops and halophytes. Crops such as corn, sorghum, rape seed and sugarcane belong to the first generation. The second-generation bioenergy crops include switchgrass, miscanthus, alfalfa, Napier grass, Reed canary grass and other plants. The third-generation bioenergy plants are comprised of micro algae, crussulacean acid metabolism (CAM) plants, boreal plants and eucalyptus. The dedicated energy crops contain woody plants and perennial herbaceous species such as switch grass, algae and jathropha. Finally, the halophytes include genera Acacia, Casurina, Melaleuca, Rhizophora and Tamarix.

According to [7], global strategies on energy consumption are incrementally decreeing an expansion of bioenergy crop production of which most are singling out second generation bioenergy crops than the first-generation crop-based fuels if they could be oriented and handled accordingly. In today's energy blend, bioenergy crops play a significant role in satisfying the energy needs for cooking, electricity generation, heating, among others. Localized bioenergy crop production is a major driver for promoting access to contemporary, clean and less costly energy, especially in rural areas with inadequate energy base.

Mississippi State has attracted many top bioenergy companies because of its agricultural production value. The availability of forest land which covers over $65 \%$ of its landscape has the potential to offer raw materials to bioenergy industries [8]. According to the words of Governor Phil Bryant, "Mississippi has become a model for other states because of our success in developing both traditional and renewable energy sources" [8] [9]. This research paper seeks to delineate land resource areas in Mississippi State which could be used for the production of bioenergy crops.

\section{Problem Statement}

During the industrial revolution in the eighteenth century, fossil fuels played a major role in solving the world's energy problems. Nevertheless, in the last few decades, the use of fossil fuels globally has become uncontrolled and unparalleled due to the rise in demand for energy by the rising human population. Presently, fossil fuels are heavily relied on to meet energy demands. However, the byproducts of energy production via fossil-based fuels have been associated with environmental degradation. The negative impacts from usage of fossil fuels have been noticed and research on alternative energy sources stepped up [6]. [10] argue that the long-term environmental impacts associated with the use of fossil fuels may eventually lead to land degradation and desertification. The surge in fossil fuel usage has been associated with, climate change, sea level rise, and climate change dependent diseases, etc.

Although the use of bioenergy could be, there are possibilities that the expansion of bioenergy crop production could cause some extreme environmental modifications. For instance, converting a piece of land from native grass to bio- 
energy crops in the Mississippi River Basin can cause a decrease in water yield, streamflow and surface run off and at the same time increase evapotranspiration and nitrogen loss [11]. Similarly, [12] explained that such an expansion may lead to food and energy conflicts and have a negative impact on food security and the market, respectively. Although scientists have tried to come up with strategies to bring a balance between bioenergy crop production and environmental protection, the issues of inadequate information and complexities of the systems have made the knowledge of the environmental effects of bioenergy production unclear.

Even though the use of bioenergy is a substitute for conventional fuels, it is speculated to be of great importance for energy security. However, the expansion of bioenergy crop production can possibly cause some extreme environmental modifications. For instance, converting a piece of land from native grass to bioenergy crops in the Mississippi River Basin can cause a decrease in water yield, streamflow and surface run off and at the same time increase evapotranspiration and nitrogen loss [11]. Similarly, [12] explained that such an expansion may lead to food and energy conflicts and have a negative impact on food security and the market, respectively. Although scientists have tried to come up with strategies to bring a balance between bioenergy crop production and environmental protection, the issues of inadequate information and complexities of the systems have made the knowledge of the environmental effects of bioenergy production unclear.

Additionally, [13] claim that bioenergy crop production could be priced at growing food crops if the land is converted to growing crops for fuel or at the cost of wildlife habitats or cultural resources if protected areas are used for bioenergy production. The land use conundrum for bioenergy production is taxing scientists to determine exactly where to grow bioenergy crops to meet energy needs whilst at the same time ensuring a long-lasting food production and environmental protection. Many have suggested the use of marginal lands as a probable sustainable quick fix to the dilemma since the second-generation biofuels are known for their ability to grow on non-prime agricultural land.

The global abundance of marginal lands as a workable solution to bioenergy crop production whilst simultaneously maximizing net carbon security have validated bioenergy as a viable energy resource. Current research approves growing bioenergy crops on marginal lands as energy policies have endorsed the expansion of bioenergy production. In due course, there has been a rise in published literature which use the Geographic Information Systems to map the accessibility of marginal land as a stand-in for bioenergy crop potential [14]. However, scholarly documentation on the use of fertile lands for bioenergy crop production is limited, and will be the gap to this research. This article seeks to provide a bridge in the current knowledge gap that exists in the subject area.

\section{Background of the Research}

Mississippi is characterized by broad divisions of land resource areas (MLRA 
131A, MLRA 134 and other MLRA areas in the south of the Gulf Coast and east bordering Alabama (Figure 1); [15] [16]. These divisions are characterized by or based on particular patterns of soils, geology, climate, water resources and land use [17].

\section{The MLRA 131A Areas}

This area forms part of the alluvial deposits of many years ago from flooding and lateral movement of the Mississippi River. These sediments range from sandy to clayey deposits. The major soils in this area are Alfisols, vertisols and Entisols [17]; Figure 2. A representative of this soil type in the area is shown in Figure 2 and Figure 3. The topography ranges from nearly level to undulating in some areas. Major crops in this area are cotton, corn, wheat, rice, grain, sorghum, soybeans, and sugarcane.

\section{The MLRA 134 Areas}

This area stretches from the northwest of the state along the Natchez to the southwestern part in Louisiana (Figure 1). The area is composed of valleys and ridges. The ridges range from steep, narrow, broad, and flat in the upper areas. The dominant soil forms part of the Natchez series-dark grayish brown silt loam and yellowish-brown silt loam [17]. A pictorial representation of this soil type is shown in Figure 4 below. Cotton, corn, rice, soybeans, and wheat are the major crops.

\section{Other MLRA Areas}

It consists of other areas such as 133A. It stretches from the northeastern corner of Mississippi down to the Central area of the State to the Southern Coastal Plain (Figure 1). The dominant soils are Aquepts, Aqualfs, Aquents, Udolls, and Udalfs. These soils are deep, medium textured and fine textured soils that have an udic

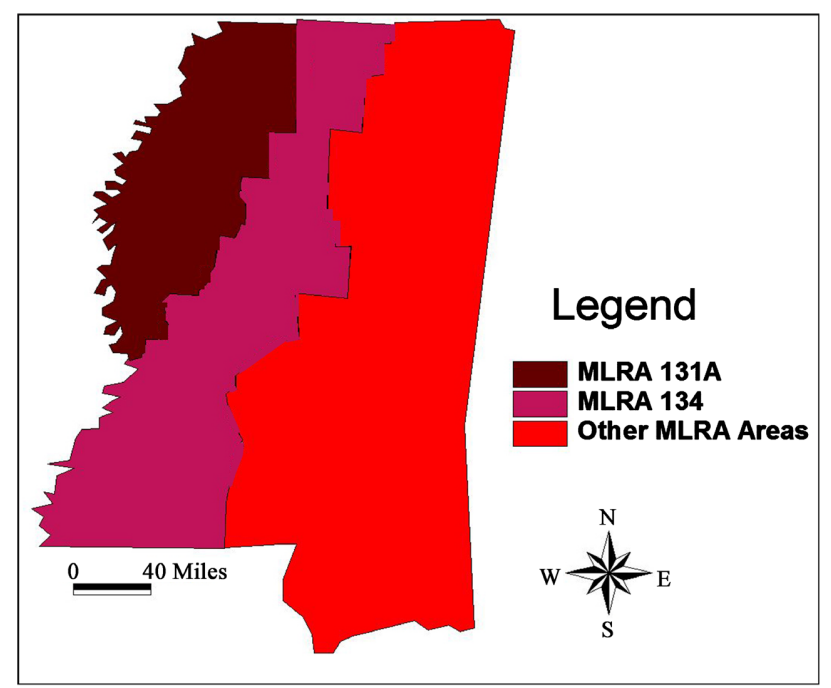

Figure 1. Mississippi land resource areas (MLRA) [15] [16]. 
or aquic moisture regime. Some cash crops include soybeans, corn, peanuts, and cotton [17]. Major vegetable crops such as melons, tobacco, and pecans are important in some parts of the area. A pictorial description of this soil type is represented in the area shown in Figure 5 below.

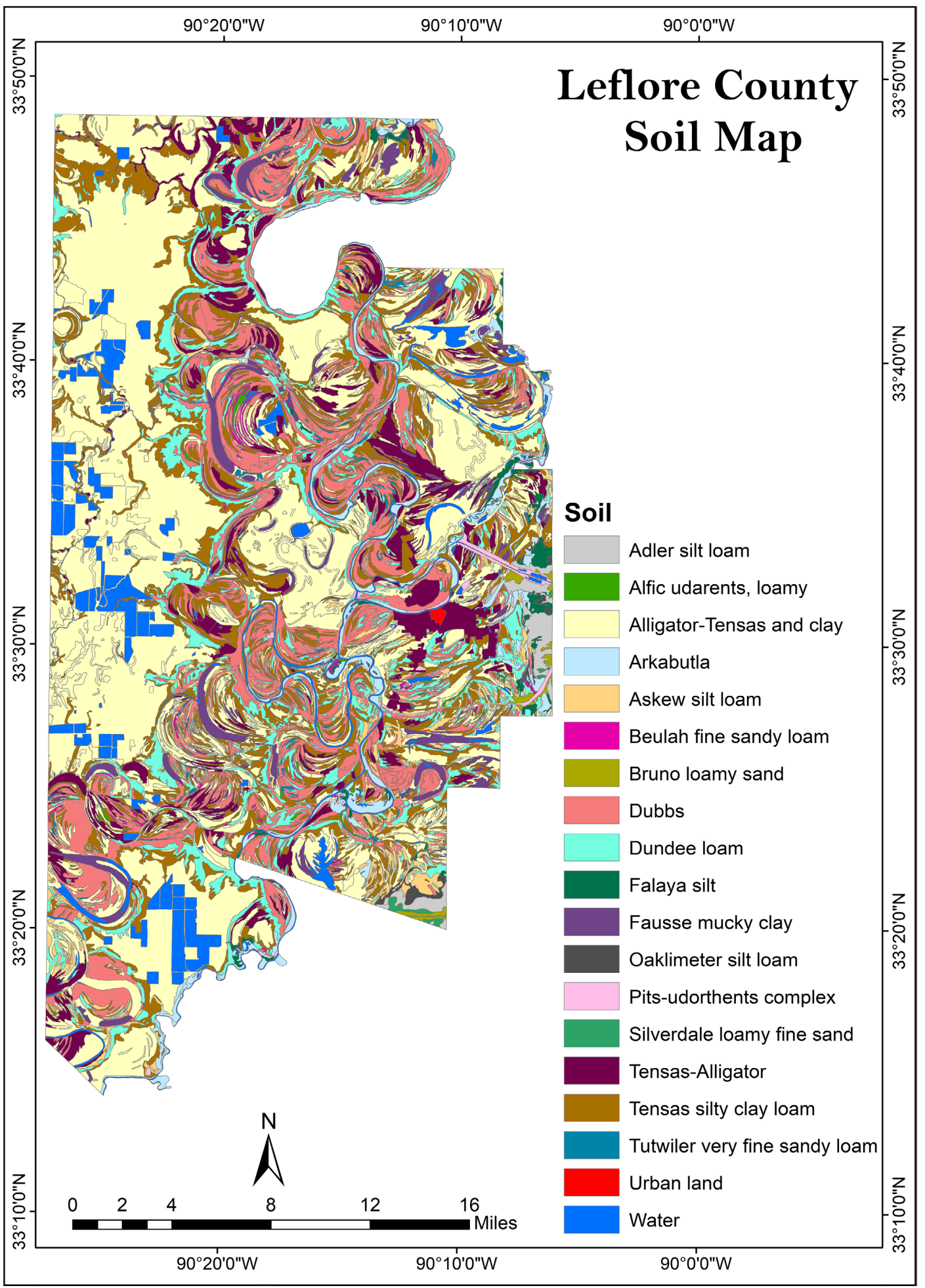

Figure 2. Leflore county soil map. 


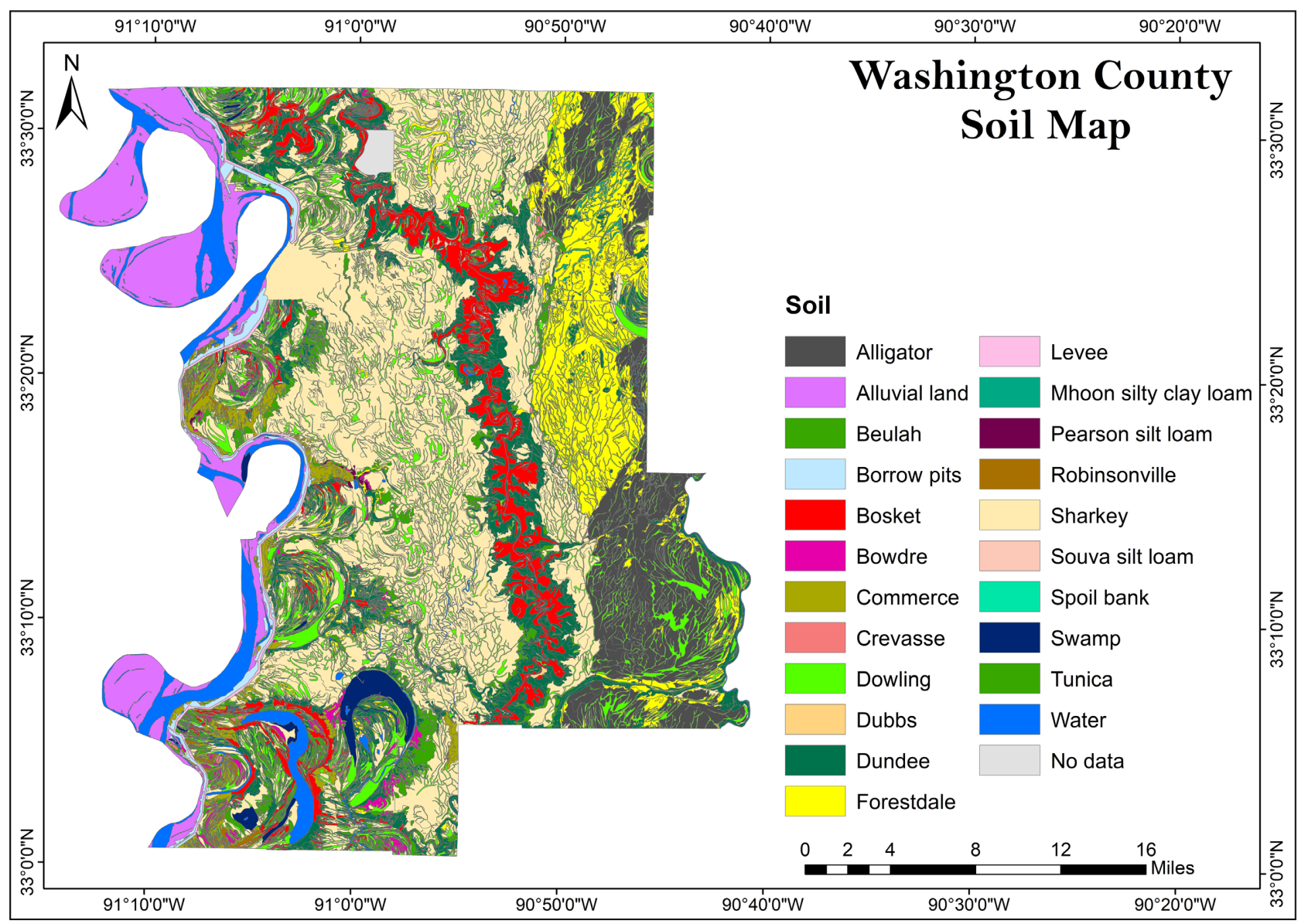

Figure 3. Washington county soil map.

\section{Materials and Methods}

\subsection{Materials}

The data used were collected from the United States Department of Agriculture, National Agricultural Statistical Service [18] [19]. The Agricultural census data [20] [21] [22] from Mississippi State on district levels were used to generate the analysis of this research. The districts in Mississippi State are represented with districts codes as shown below in Table 1 .

The commodities under study were measured in the following units: corn (Bushels (BU)), cotton (Bales), rice (Hundredweight (CWT)), soybeans (Bushels $(\mathrm{BU})$ ), and wheat (Bushels (BU)). To make an accurate comparison and a uniform decision, all the units were converted to Pounds (lbs.), using the United States Department of Agriculture conversion factors for agricultural commodities [22]. 1 bale of Cotton $=480$ lbs., $1 \mathrm{BU}$ of Corn $=56$ lbs., $1 \mathrm{BU}$ of Soybean and Wheat $=60 \mathrm{lbs}$., and $1 \mathrm{CWT}$ of rice $=100 \mathrm{lbs}$. [22]. After the conversion, descriptive statistics was employed to discuss the production of plant-based energy crops in Mississippi. The agricultural census data was transformed into relative measures. These measures established changes in production within districts and within the years and the identified percentage production, increasing 


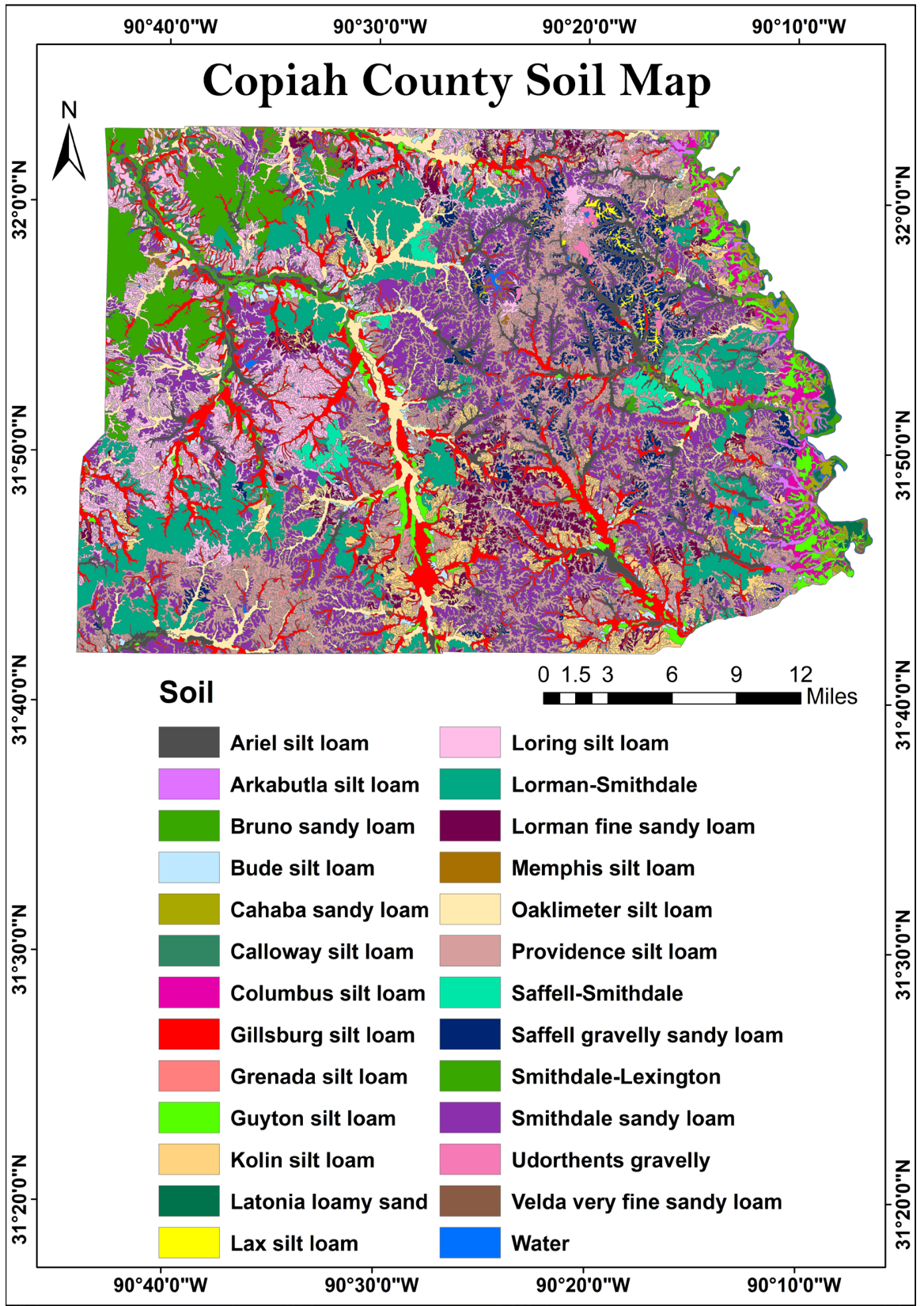

Figure 4. Mississippi copiah county soil map.

and decreasing characteristics and patterns of crop production from each district. Time series graphs generate the characteristics of variables over time and space, it also describes trends the variables describe.

\subsection{GIS Data Mapping}

Data for wheat, corn, cotton, and soybeans, obtained from [19] [20] [21] [22] was inputted into the ArcMap attribute table. The inputted data was sent to ArcMap Symbology to map the spatial distribution of the biofuel crops. All Mississippi States' agricultural districts and codes were similarly created in the ArcMap attribute table and symbology features used to map them. 


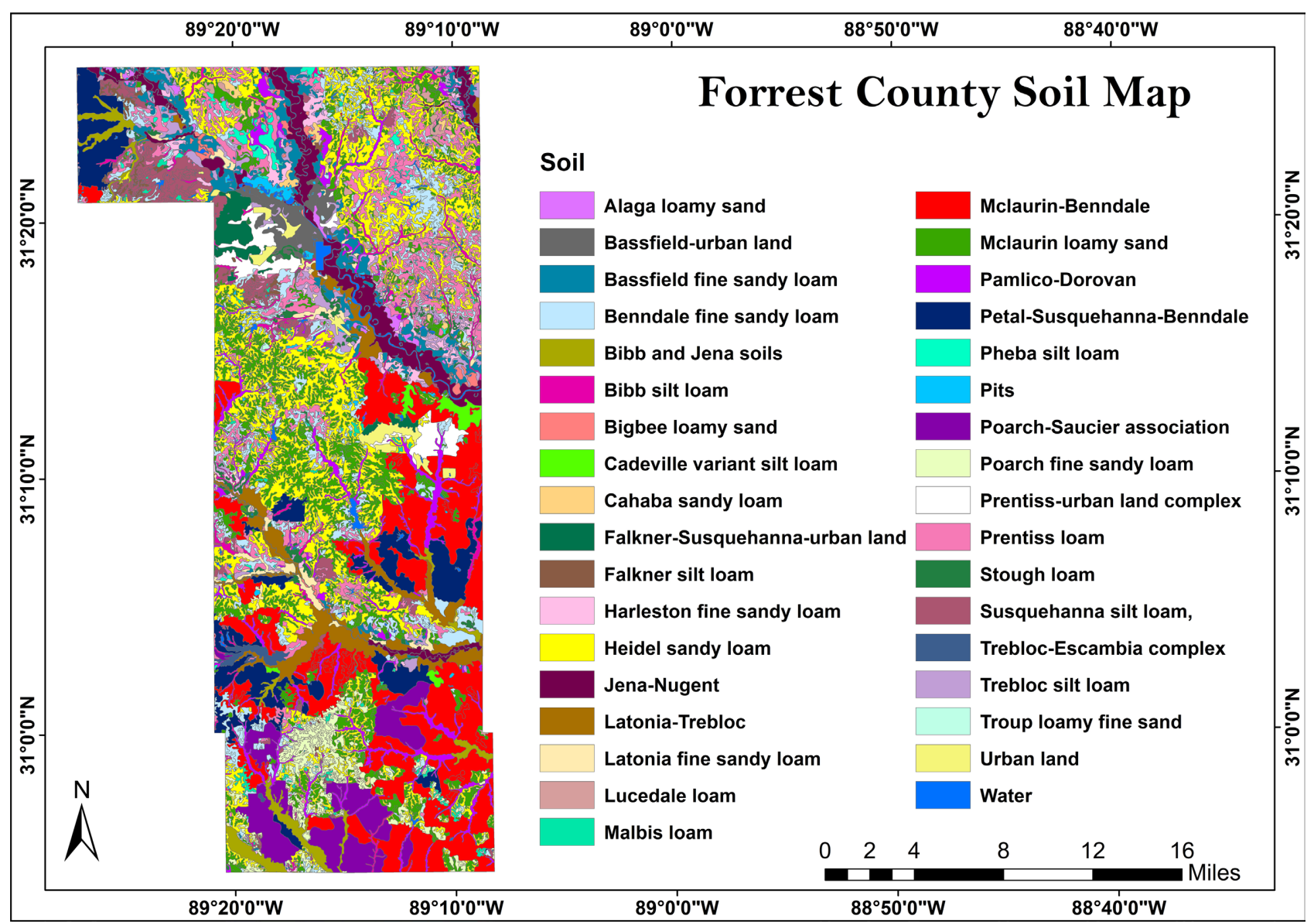

Figure 5. Forrest county soil map.

Table 1. District codes.

\begin{tabular}{cc}
\hline District & Agricultural District Code \\
\hline Central & 50 \\
East Central & 60 \\
Lower Delta & 40 \\
North Central & 20 \\
Northeast & 30 \\
South Central & 80 \\
Southeast and Coastal & 90 \\
Southwest & 70 \\
Upper Delta & 10 \\
\hline
\end{tabular}

\section{Results and Discussion of the Statistical Analysis}

\subsection{Plant-Based Energy Crop Production}

Mississippi State has to a large extent produced a variety of plant-based energy crops (Table 2). In 1997, the state produced $8,726,618,476$ lbs. plant-based 
energy crops with soybeans' $(3,645,060,420$ lbs.) being the most produced crop.

The least crop produced in 1997 was cotton. Similarly, 13,349,856,488 lbs. plant-based energy crops were produced in 2007. The least produced crop was cotton $(609,858,720$ lbs.) and the most produced crop was corn $(7,124,986,848$ lbs.). In 2017 , a total of $13,608,920,924$ lbs. plant-based energy crops was produced in Mississippi State, with soybeans $(6,852,640,980$ lbs.) being again the most produced crop, followed closely by corn $(5,221,746,544$ lbs.) with Wheat $(69,960,360$ lbs.), being the least. A total of $35,685,395,888$ lbs. of crops was produced over the 20 years range under study. Corn $(14,844,195,688$ lbs.) was the highest plant-based energy crop produced while wheat $(1,525,378,200 \mathrm{lbs}$.) was the least produced over the years under consideration. As presented on Table 2, the most produced crop in the state differed each year. However, corn and soybeans topped when the grand total production list respectively.

The plant-based energy crops produced in all the nine agricultural districts of Mississippi are presented in Table 3. District 40 recorded the highest number of plant-based energy crops (3,330,616,208 lbs.) in 1997 followed by District 10

Table 2. Descriptive statistics.

\begin{tabular}{ccccc}
\hline \multicolumn{5}{c}{ Production in Mississippi (lbs) } \\
\hline $\begin{array}{c}\text { Plant-based } \\
\text { Energy Crop }\end{array}$ & 1997 & 2007 & 2017 & Grand Total \\
\hline Corn & $2,497,462,296$ & $7,124,986,848$ & $5,221,746,544$ & $14,844,195,688$ \\
Cotton & $870,181,440$ & $609,858,720$ & $641,451,840$ & $2,121,492,000$ \\
Rice & $1,320,616,000$ & $1,312,405,700$ & $823,121,200$ & $3,456,142,900$ \\
Soybeans & $3,645,060,420$ & $3,240,485,700$ & $6,852,640,980$ & $13,738,187,100$ \\
Wheat & $393,298,320$ & $1,062,119,520$ & $69,960,360$ & $1,525,378,200$ \\
Grand Total & $8,726,618,476$ & $13,349,856,488$ & $13,608,920,924$ & $35,685,395,888$ \\
\hline
\end{tabular}

Table 3. Plant-based energy crop produced in Mississippi from 1997-2017.

\begin{tabular}{ccccc}
\hline \multicolumn{5}{c}{ Plant-based Energy Crop Produced (lbs.) } \\
\hline District & 1997 & 2007 & 2017 & Grand Total \\
\hline District 10 & $2,921,402,340$ & $4,153,352,652$ & $4,004,934,288$ & $11,079,689,280$ \\
District 20 & $867,886,984$ & $946,550,464$ & $863,049,844$ & $2,677,487,292$ \\
District 30 & $351,206,436$ & $432,784,076$ & $561,814,908$ & $1,345,805,420$ \\
District 40 & $3,330,616,208$ & $6,014,715,452$ & $6,113,213,676$ & $15,458,545,336$ \\
District 50 & $449,624,448$ & $793,152,808$ & $781,327,676$ & $2,024,104,932$ \\
District 60 & $479,936,692$ & $543,710,524$ & $871,287,836$ & $1,894,935,052$ \\
District 70 & $223,896,396$ & $392,434,396$ & $291,005,220$ & $907,336,012$ \\
District 80 & $43,632,308$ & $41,762,792$ & $76,613,620$ & $162,008,720$ \\
District 90 & $58,416,664$ & $31,393,324$ & $45,673,856$ & $135,483,844$ \\
\hline
\end{tabular}


$(2,921,402,340 \mathrm{lbs}$.). District 80 (43,632,308 lbs.) produced the least of the crops. In 2007, District 40 again produced the highest plant-based energy crops $(6,014,715,452$ lbs.), District 10 produced the second highest plant-based energy crops $(4,153,352,652 \mathrm{lbs}$.) and District 90 produced the least crops $(31,393,324$ lbs.) compared to all the other districts. District 40 produced the most plantbased energy crops in 2017 followed by District 10 with District 90 (45,673,856 lbs.) again producing the least. Perceptibly, District 40 produced 15,458,545,336 lbs. plant-based energy crops representing $43.32 \%$ of all plant-based energy crops produced in Mississippi over the 20-year span. District 10 produced $11,079,689,280$ lbs. plant-based energy crops representing 31.05\%. District 80 and District 90 produced $0.45 \%$ and $0.38 \%$ respectively of total crops. This indicates that District 40 and District 10 produce majority of the plant-based energy crops in Mississippi. District 40 and District 10 can therefore be said to be the two districts which produce a greater part of plant-based energy crops in the state of Mississippi. This trend has been consistent over all the fiscal years under consideration.

\subsection{Time Graph and Trend Analysis}

Figure 6 describes the time graph for all plant-based energy crops considered in Mississippi. There was a fluctuation in the quantity of corn produced even though it recorded the highest production. Corn had a drastic increase in its production from 1997 to 2007 but turned to decrease greatly from 2007 to 2017. This characteristic makes it difficult to associate any trend with corn production. The production of soybeans marginally from 1997 to 2007, and then rose from 2007 to 2017, exceeding the productions of corn, cotton, rice, and wheat, respectively. Soybeans' production followed an upward trend. Cotton is a crop that is not popular in Mississippi, this can be observed in its flat line. Cotton' production followed a negative linear trend, representing marginal drop in its production. The production of rice displayed a steady decreasing trend, an indication of a possible reduction in rice production in the 2017 agricultural census. Wheat

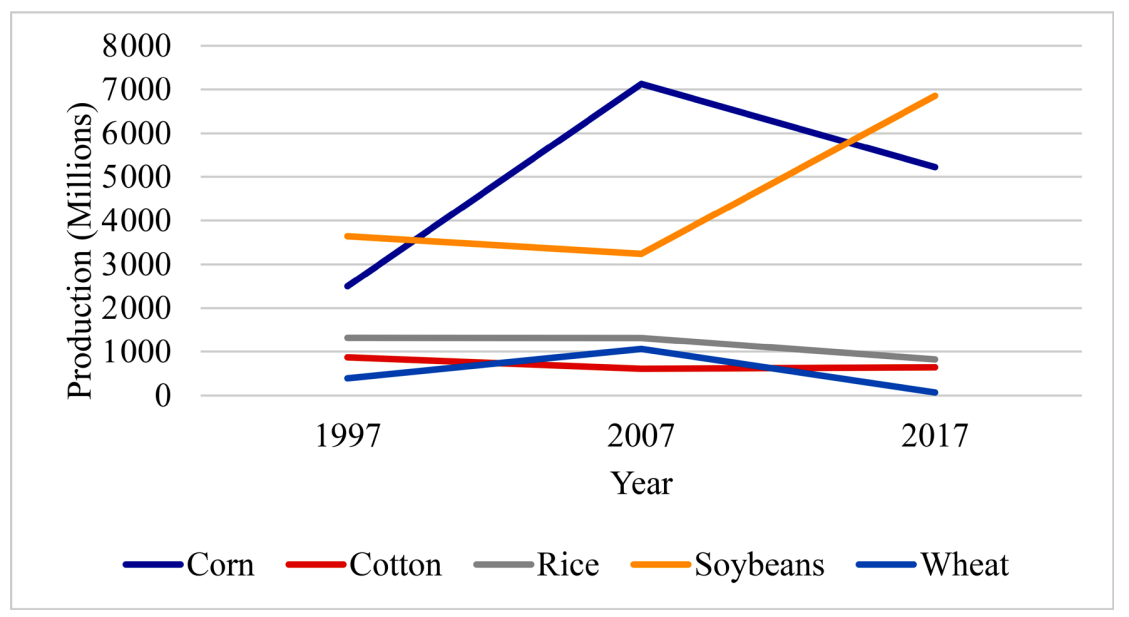

Figure 6. Time graph of Plant-based energy crops in Mississippi. 
production increased greatly in 2007 from 1997 but declined sharply in 2017. Again, no specific trend can be associated with the production of wheat in Mississippi.

\subsection{Percentage Change in Production}

The percentage change in all plant-based energy crops considered in this study are duly presented in Table 4. A positive percentage indicates an increase in production of the crop within the range under discussion whilst a negative percentage indicates a decrease in production of the crop. Corn production observed an increase of $185.29 \%$ from 1997 to 2007 whilst the production declined by $26.71 \%$ from 2007 to 2017 . The production of wheat increased to a rate of $170.05 \%$, indicating that, wheat produced during the period 1997-2007 was more than the quantity produced in the previous decade. The table also indicates that rice production decreased from both decades. Table 4 illustrates that there was an extreme decrease in wheat production from 2007 to 2017. These changes demand further research to determine the factors responsible for the drastic decrease in the production of the stated crops in Mississippi State. Soybeans' production decreased at $11.1 \%$ from 1997 to 2007 but however, increased significantly from 2007 to 2017 at $111.47 \%$. Cotton production also followed a similar trend, with a reduction in production during the period, 1997 to 2007 and a slight increase in production the last decade.

Table 4. Percentage change in Plant-based energy crop production.

\begin{tabular}{ccc}
\hline Plant-based Energy Crop & 1997-2007 (\%) & 2007-2017 (\%) \\
\hline Corn & 185.29 & -26.71 \\
Cotton & -29.92 & 5.18 \\
Rice & -0.62 & -37.28 \\
Soybeans & -11.10 & 111.47 \\
Wheat & 170.05 & -93.41 \\
\hline
\end{tabular}

Table 5. Percentage change in Plant-based energy crop production within districts.

\begin{tabular}{ccc}
\hline Districts & 1997-2007 (\%) & 2007-2017 (\%) \\
\hline District 50 & 105.70 & -6.35 \\
District 60 & 16.43 & 54.08 \\
District 40 & 106.6 & 3.45 \\
District 20 & 9.65 & -11.49 \\
District 30 & 24.35 & 24.92 \\
District 80 & -6.36 & 83.94 \\
District 90 & -45.81 & 40.87 \\
District 70 & 93.44 & -28.37 \\
District 10 & 55.73 & -2.81 \\
\hline
\end{tabular}


The percentage changes within the districts are presented in Table 5. Despite District 10 being the district with the second most produced plant-based energy crops in Mississippi State as indicated in Table 3, the district only increased its production to $55.73 \%$ and had a drop in production by $2.81 \%$ the following decade. Interestingly, although Districts 80 and District 90 were ranked lowest in production, they both increased their production of plant-based energy crops by 83.94\% and $40.87 \%$ respectively from 2007 to 2017 . The increase in production in District 40 from 1997 to 2007 was $106.6 \%$ and 2007 to 2017 was just $3.45 \%$. Districts 30 and 60 also recorded a slight increase in the production of the plant-based energy crops in both decades.

\subsection{Total Plant-Based Energy Crop Production}

The percentage of plant-based energy crops produced by each agricultural district in the census year 1997 are displayed in Table 6. The total production of corn, cotton, rice, soybeans, and wheat for 1997 census year were 2,497,462,296 lbs., 870,181,440 lbs., 1,320,616,000 lbs., 3,645,060,420 lbs., and 393,298,320 lbs., respectively. Corn was produced in every district, with District 40 producing the largest quantity. The district produced $34.4 \%$ of the total corn produced in Mississippi. District 20 produced $17.2 \%$ followed closely by District 10 which produced $16.0 \%$. The district with the least production of corn was District 80 . Cotton was the most produced bioenergy crop in District 40 with $42.9 \%$ of the total production. District 10 produced $31.2 \%$ of cotton. However, there was no recorded cotton production in District 80 . Rice production occurred in only three districts. District 10 produced $54.5 \%$, District 40 produced $43.9 \%$ and District 20 produced $1.6 \%$. Soybeans' production was the most popular within the agricultural districts in Mississippi. District 40 produced 37.6\% followed closely by District 10 with $37.1 \%$ of the production. District 80 produced $0.1 \%$. Production of soybeans occurred in all the nine agricultural districts. Wheat was most

Table 6. Percentages of Plant-based energy crop production in Mississippi in 1997.

\begin{tabular}{lccccc}
\hline \multirow{2}{*}{ District } & \multicolumn{5}{c}{1997} \\
\cline { 2 - 6 } & Corn (\%) & Cotton (\%) & Rice (\%) & Soybeans (\%) & Wheat (\%) \\
\hline District 10 & 16.0 & 31.2 & 54.5 & 37.1 & 45.4 \\
District 20 & 17.2 & 8.2 & 1.6 & 8.6 & 8.2 \\
District 30 & 5.9 & 1.2 & 0.0 & 5.2 & 0.8 \\
District 40 & 34.4 & 42.9 & 43.9 & 37.6 & 37.9 \\
District 50 & 8.6 & 10.8 & 0.0 & 3.6 & 2.0 \\
District 60 & 11.1 & 2.2 & 0.0 & 4.7 & 2.7 \\
District 70 & 3.7 & 3.2 & 0.0 & 2.8 & 0.3 \\
District 80 & 1.4 & 0.0 & 0.0 & 0.1 & 1.3 \\
District 90 & 1.6 & 0.3 & 0.0 & 0.3 & 1.4 \\
\hline
\end{tabular}


produced in Districts $10(45.4 \%)$ and $40(37.9 \%)$. Although wheat was produced in all the districts, the total production was low in comparison to other plant-based energy crop which could be because of the production of wheat in small scale in all the districts.

Table 7 describes the production of the various plant-based energy crops produced within the census year 2007. The total production of corn, cotton, rice, soybeans, and wheat for 2007 were 7,124,986,848 lbs., 609,858,720 lbs., 1,312,405,700 lbs., 3,240,485,700 lbs., and 1,062,119 lbs. respectively. Corn production in District 40 increased to $50.5 \%$ although the total corn produced also increased as compared to 1997 . District 10 also produced $20.6 \%$ of the total corn produced. District 80 produced the least corn. Cotton production did not record a great change in each district. District 40 produced $41 \%$ whilst District 10 produced $34.1 \%$. Rice was produced in Districts 10 (57.3\%), 20 (5.3\%) and 40 (37.4\%). All the other districts did not produced rice. Soybean production continues to be the most popular amongst the districts. District 40 still produced the most soybean for the 2007 census year. The district produced $41.1 \%$ of the total soybean production. District 10 produced $37.9 \%$ whiles District 90 produced $0.1 \%$. Wheat production in District 10 was $47 \%$ whereas District 40 recorded $31.5 \%$ of the total wheat produced within the census year 2007. The production of wheat in District 90 dropped to zero.

Table 8 displays the production of plant-based energy crops in Mississippi for the census year 2017. The total production of corn, cotton, rice, soybeans, and wheat for 2007 were 5,221,746,544 lbs., 641,451,840 lbs., 823,121,200 lbs., 6,852,640,980 lbs., and 69,960,360 lbs. respectively. The production of corn was least in District 90 with $0.4 \%$ whereas the most production occurred in District 40 with $48.5 \%$ of the production. District 10 produced $20.2 \%$ of the corn within the 2017 census year. Remarkably, District 60 increased corn production after a reduction in production in 2007. District 10 produced the most cotton in the census year.

Table 7. Percentages of Plant-based energy crop production in Mississippi in 2007.

\begin{tabular}{lccccc}
\hline \multirow{2}{*}{ District } & \multicolumn{5}{c}{$\mathbf{2 0 0 7}$} \\
\cline { 2 - 6 } & Corn (\%) & Cotton (\%) & Rice (\%) & Soybeans (\%) & Wheat (\%) \\
\hline District 10 & 20.6 & 34.1 & 57.3 & 37.9 & 47.0 \\
District 20 & 6.4 & 8.3 & 5.3 & 7.8 & 10.9 \\
District 30 & 3.2 & 2.0 & 0.0 & 4.7 & 3.5 \\
District 40 & 50.5 & 41.0 & 37.4 & 41.1 & 31.8 \\
District 50 & 8.5 & 9.4 & 0.0 & 3.2 & 2.6 \\
District 60 & 5.7 & 2.0 & 0.0 & 3.3 & 1.5 \\
District 70 & 4.3 & 3.0 & 0.0 & 1.6 & 1.3 \\
District 80 & 0.3 & 0.0 & 0.0 & 0.2 & 1.3 \\
District 90 & 0.4 & 0.2 & 0.0 & 0.1 & 0.0 \\
\hline
\end{tabular}


Table 8. Percentages of Plant-based energy crop production in Mississippi in 2017.

\begin{tabular}{cccccc}
\hline \multirow{2}{*}{ District } & \multicolumn{5}{c}{2017} \\
\cline { 2 - 6 } & Corn (\%) & Cotton (\%) & Rice (\%) & Soybeans (\%) & Wheat (\%) \\
\hline District 10 & 20.2 & 34.3 & 66.4 & 31.5 & 41.0 \\
District 20 & 5.3 & 10.0 & 7.3 & 6.4 & 33.3 \\
District 30 & 2.8 & 4.4 & 0.0 & 5.6 & 4.5 \\
District 40 & 48.5 & 26.6 & 26.3 & 46.5 & 11.3 \\
District 50 & 8.9 & 13.9 & 0.0 & 3.3 & 0.0 \\
District 60 & 10.2 & 7.7 & 0.0 & 4.1 & 6.3 \\
District 70 & 2.9 & 2.9 & 0.0 & 1.8 & 3.6 \\
District 80 & 0.8 & 0.0 & 0.0 & 0.5 & 0.0 \\
District 90 & 0.4 & 0.4 & 0.0 & 0.3 & 0.0 \\
\hline
\end{tabular}

District 40 reduced in cotton production whilst District 50 increased cotton production. Rice production in District 40 reduced, with only $26.3 \%$ being produced. District 10 produced $66.4 \%$, which was the highest the district had produced over the two decades. Soybean production in District 40 was at $46.5 \%$ and production in District 10 was $32.5 \%$. The least soybeans production was recorded in District 90. Districts 80 and 90 did not produce wheat. District 10 produced the most wheat with District 20 contributing 33.3\% to the production of wheat. Wheat production in District 40 was $11.3 \%$, thereby showing a huge reduction in wheat production in the district as compared to the previous production trends in the district.

To compare the means of the total annual productions of all the biofuel crops for the state of Mississippi, the approach by [23] used. In this method, the probability generator function for normal distribution was used to generate sets of 30 random numbers for the years 1997, 2007 and 2017, respectively, based on the total productions for each year being used to represent the means of the normal distributions. Quantities smaller than 5\% of the mean were used to represent the standard deviations of the total productions of each year. The generated data is presented in Table 9.

An Anova test was run using Microsoft Excel data analysis tool kit to compare the means of the total annual productions of all the biofuel crops for the state of Mississippi. The results are presented in Table 10. The F value was found to be 889.30, while the critical $F$ value was found to be 3.1907 . Since $F$ was greater than the critical value of $\mathrm{F}$, the means of at least one pair of data from the total productions for Mississippi State had a statistically significant difference. $\mathrm{P}<0.05$ (1.23E-58).

Paired tests were carried out to determine the data pairs whose productions difference were statistically significant. Table 11 represents the outcomes of T-test between 1997 and 2007 data sets and Table 12, the output of T-test for comparison of 2007 and 2017. 


\section{Results of the GIS Mapping and Discussions}

The map of Mississippi Agricultural Districts is illustrated in Figure 7. Results of

Table 9. Generated data sets of total production of bioenergy crops for the years, 1997, 2007 and 2017, respectively.

\begin{tabular}{|c|c|c|}
\hline $\begin{array}{l}1997 \text { total production } \\
\text { (Lbs.) }\end{array}$ & $\begin{array}{c}2007 \text { total production } \\
\text { (Lbs.) }\end{array}$ & $\begin{array}{l}2017 \text { total production } \\
\text { (Lbs.) }\end{array}$ \\
\hline $9,000,000,000$ & $13,640,000,000$ & $13,530,000,000$ \\
\hline $8,650,000,000$ & $12,920,000,000$ & $13,200,000,000$ \\
\hline $8,510,000,000$ & 13,270000000 & $13,120,000,000$ \\
\hline $8,590,000,000$ & 13,940000000 & $13,490,000,000$ \\
\hline $8,910,000,000$ & 13,730000000 & $13,150,000,000$ \\
\hline $8,740,000,000$ & 13,370000000 & $13,720,000,000$ \\
\hline $9,110,000,000$ & $12,350,000,000$ & $13,010,000,000$ \\
\hline $8,630,000,000$ & $13,570,000,000$ & $13,920,000,000$ \\
\hline $8,510,000,000$ & $13,380,000,000$ & $12,500,000,000$ \\
\hline $8,590,000,000$ & $13,650,000,000$ & $12,680,000,000$ \\
\hline $8,940,000,000$ & $13,310,000,000$ & $14,140,000,000$ \\
\hline $8,460,000,000$ & $13,720,000,000$ & $14,480,000,000$ \\
\hline $8,280,000,000$ & $12,710,000,000$ & $14,170,000,000$ \\
\hline $9,010,000,000$ & $12,780,000,000$ & $14,220,000,000$ \\
\hline $8,480,000,000$ & $13,150,000,000$ & $13,910,000,000$ \\
\hline $8,470,000,000$ & 13,030000000 & $13,160,000,000$ \\
\hline $9,180,000,000$ & 14,030000000 & $13,860,000,000$ \\
\hline $8,810,000,000$ & $13,870,000,000$ & $13,700,000,000$ \\
\hline $8,990,000,000$ & $13,560,000,000$ & $13,150,000,000$ \\
\hline $8,610,000,000$ & $12,140,000,000$ & $12,500,000,000$ \\
\hline $8,540,000,000$ & $14,210,000,000$ & $13,490,000,000$ \\
\hline $8,960,000,000$ & $13,030,000,000$ & $14,300,000,000$ \\
\hline $8,990,000,000$ & $13,020,000,000$ & $12,940,000,000$ \\
\hline $9,120,000,000$ & $13,120,000,000$ & $14,360,000,000$ \\
\hline $8,670,000,000$ & $12,710,000,000$ & $13,160,000,000$ \\
\hline $8,520,000,000$ & $12,150,000,000$ & $12,670,000,000$ \\
\hline $8,270,000,000$ & $13,730,000,000$ & $12,190,000,000$ \\
\hline $8,830,000,000$ & $13,570,000,000$ & $14,010,000,000$ \\
\hline $8,950,000,000$ & $13,160,000,000$ & $13,070,000,000$ \\
\hline $8,760,000,000$ & $13,340,000,000$ & $13,330,000,000$ \\
\hline
\end{tabular}


Table 10. Anova test results for comparison of means of randomly generated data from the total of bioenergy crops for m1997, 2007 and 2017, for Mississippi, respectively.

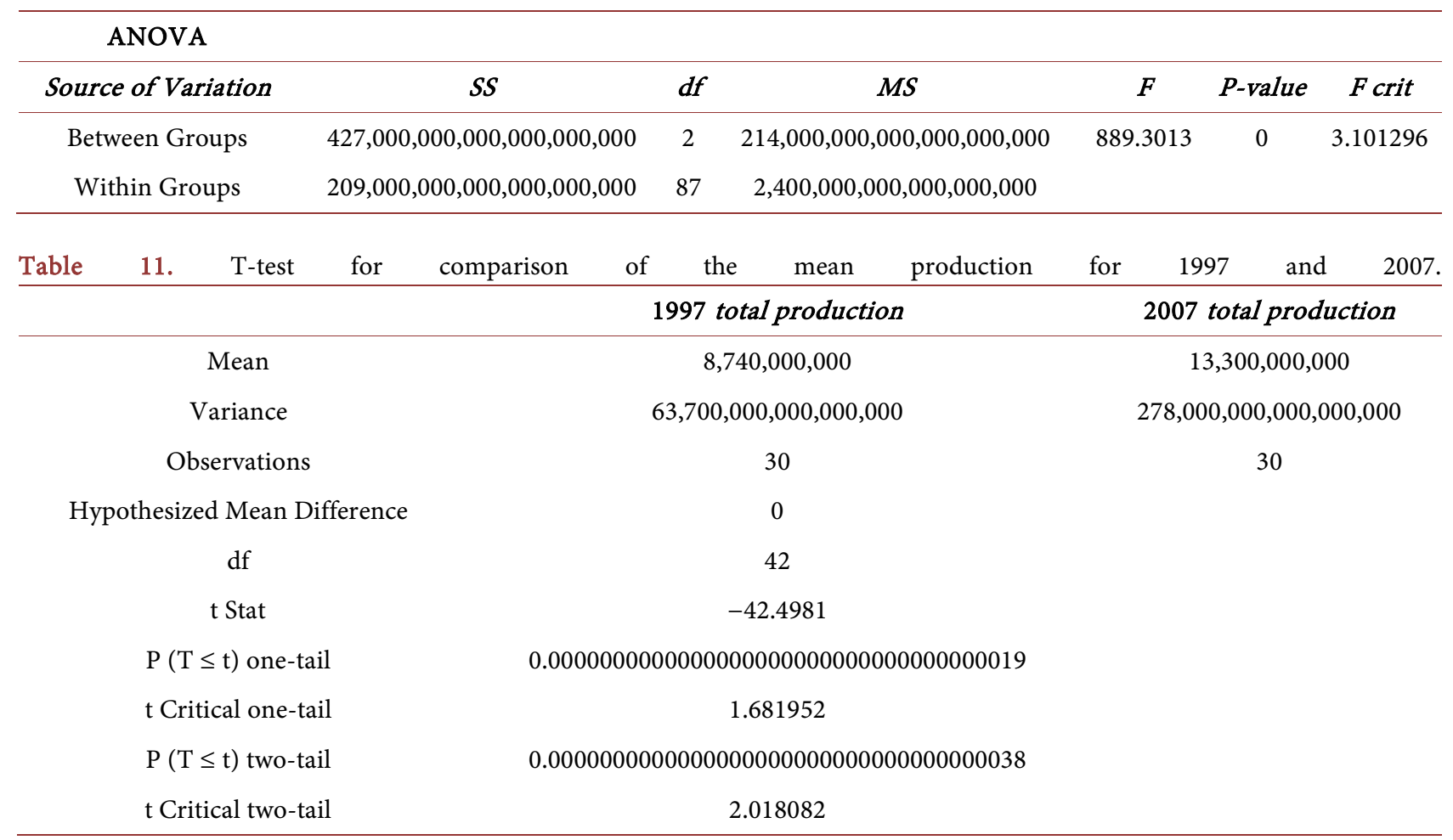

As Table 11 shows, $\mathrm{p}<0.05$, hence the difference in total production in 1997 and 2007 was statistically significant.

Table 12. T-test for comparison of the mean production for 2007 and 2017.

\begin{tabular}{ccc}
\hline & 2007 total production & 2017 total production \\
\hline Mean & $13,300,000,000$ & $13,400,000,000$ \\
Variance & $278,000,000,000,000,000$ & $379,000,000,000,000,000$ \\
Observations & 30 & 30 \\
Pooled Variance & 328000000000000000 & \\
Hypothesized Mean Difference & 0 & \\
df & 58 \\
t Stat & -1.11975 \\
$\mathrm{P}(\mathrm{T}<=\mathrm{t})$ one-tail & 0.133717 \\
$\mathrm{t}$ Critical one-tail & 1.671553 \\
$\mathrm{P}(\mathrm{T}<=\mathrm{t})$ two-tail & 0.267435 \\
$\mathrm{t}$ Critical two-tail & 2.001717
\end{tabular}

As Table 12 shows, $\mathrm{p}>0.05$, hence the difference in total production in 1997 and 2007 was not statistically significant.

2007 corn and cotton production in Mississippi are shown in Figure 8 and Figure 9. Figure 10 and Figure 11 shows 2007 and 2018 soybeans production in Mississippi. 


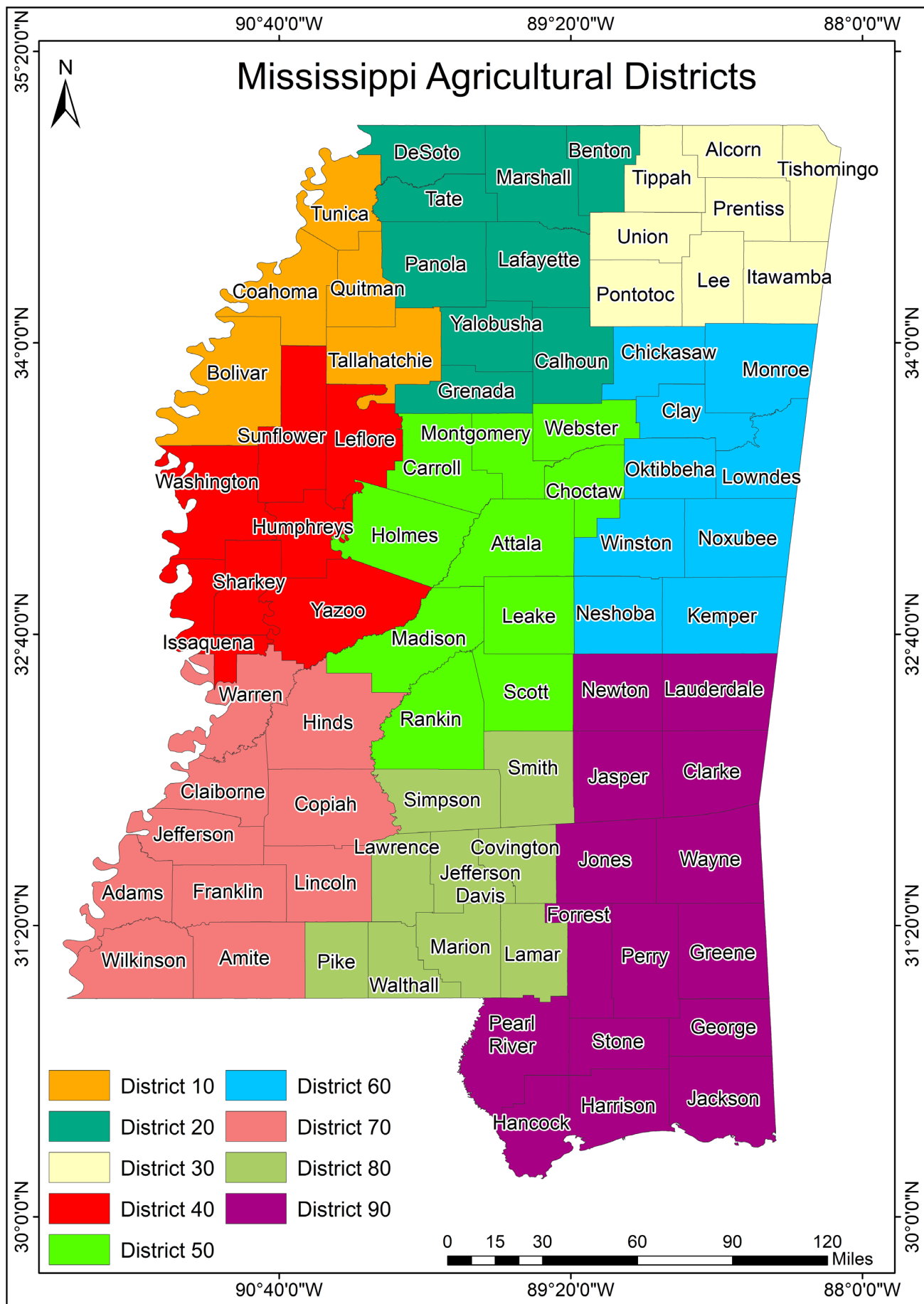

Figure 7. Mississippi agricultural districts.

\subsection{Corn Production in Mississippi}

Even though corn production has never been associated with Mississippi, it has made significant contributions throughout the history of the state, first as an important crop to the agricultural and religious ritual of Chickasaw and Choctaw then as a food crop for human consumption in the nineteenth century. Currently, it has become a major bioenergy crop in the twenty-first century. Missis- 
sippi as a state has never been identified as one of the country's top producers of corn. Although it placed seventeenth in 2013, the diverse history of corn production indicates how agriculture has taken different forms over the years [24].

Tishomingo, Lee Itawamba, Choctaw, Oktibbeha, Winston, Leake and Kempe counties in the northern part of Mississippi and Lauderdale, Clarke, Copiah, Simpson, Smith, Jasper, Adams, Franklin, Lincoln, Lawrence, Jefferson, Davis, Wilkinson, Amite, Pite, Waltham, Marion, Lamar Forrest, Perry, Greene, Pearle River, Stone, George, Hancock, Harrison and Jackson counties all in the southern part of the state produced cotton on a land area of less than 1370 acres in 2007 (Figure 8). Between 9621 and 19,327 acres of land were used in the production of

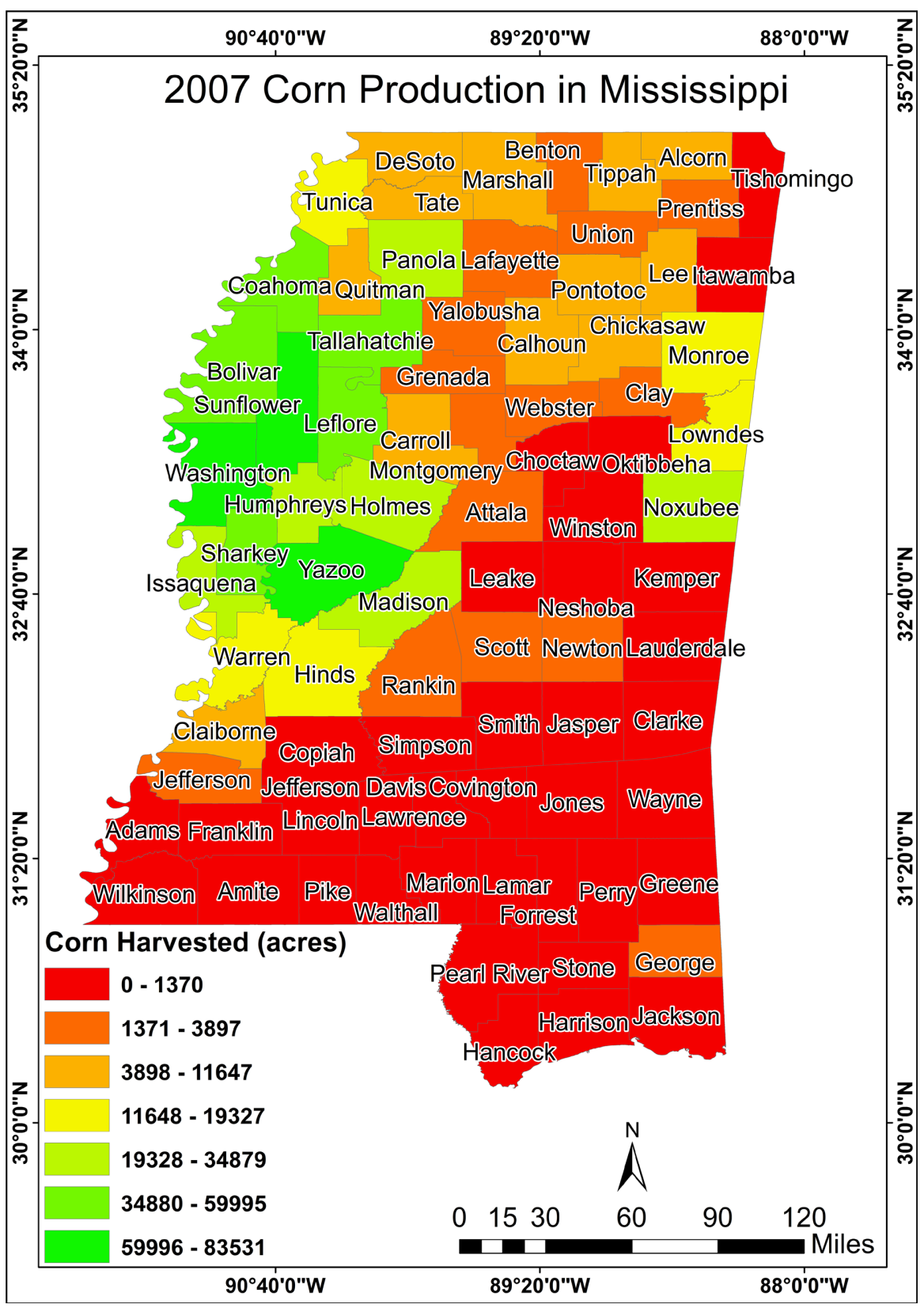

Figure 8. 2007 Corn production in Mississippi. 
corn in Warren, Hinds, Tunica, Quitman, Monroe, and Lowndes counties (Figure 8). Interestingly, a vast area of land between 52,355 and 75,414 acres were utilized in the production of corn in Sunflower, Leflore, and Washington counties (Figure 8).

\subsection{Cotton Production in Mississippi}

Cotton is one of the predominantly produced crops in Mississippi. Being ranked fourth in 2014 after poultry, forestry and soybeans in state products, the crop fetched 403 million dollars of revenue [25]. [26] reveals that, for each of the past eight years, average yields of more than 1000 pounds of cotton per acre have been harvested by farmers in Mississippi. Presently, the United States Department of Agriculture have approximated standard yields of 1115 pounds per acre.

In the year 2007, counties which covered less than 982 acres of land harvesting cotton were Brenton, Alcorn, Union, Clay, Choctaw, Oktibbeha in the north and Leake, Neshoba, Kemper, Scott, Newton, Lauderdale, Rankin, Claiborne, Copiah, Simpson, Smith, Jasper, Clarke, Adams, Franklin, Lincoln, Lawrence, Covington, Jones, Wayne, Jefferson, Wilkinson, Amite, Pike, Walthall, Marion, Lamar Forrest, Perry, Greene, Pearl River, Stone, Hancock, Harrison and Jackson located at the southern part of the state. Evidently, most of the crops were harvested in Leflore, Bolivar and Coahoma counties which were grown on between 40,956 and 80,677 acres of land (Figure 9). Additionally, there was a scattered geographical distribution of cotton production in Warren, Madison, Attala, Grenada, Desoto, Lafayette, Chickasaw, Prentiss, Lowndes, and Noxubee which covered between 3079 and 6648 acres of land. Cotton was also harvested in counties which occupied between 11,848 and 19,008 acres of land consisting of Issaquena, Quitman, Tallahatchie, and Calhoun (Figure 9).

\subsection{Soybeans Production in Mississippi}

Bolivar, Sunflower and Washington counties were the leading producers of soybeans in 2007 using between 105,464 and 175,870 acres of land followed by Tunica, Coahoma, Quitman, Tallahatchie, and Leflore counties located at the northwestern part of the state which used between 60,062 and 105,463 acres of land for production respectively (Figure 10 and Figure 11). Soybeans were also grown in Sharkey, Humphreys, Lee, and De Soto counties on land covering between 29,355 and 60,061 acres. It was also cultivated in counties whose land acreage were between 18,170 and 29,3454, which included Issaquena, Monroe, Yazoo and Holmes and to a lesser degree other parts of the southern and a few northern areas which include Covington, Jones, Wayne, Jefferson, Davis, Marion, Lamar Forrest, Walthall, Perry, Greene, Pearl River, Stone, George, Hancock, Harrison, Jackson, Tishomingo, Webster, Attala, Winston, Choctaw, Oktibbeha, Leake, Neshoba, Kemper, Scott, Newton, Lauderdale, Claiborne, Jefferson, Franklin, Wilkinson, Franklin, Amite, Copiah, Lincoln, Pike, Simpson, Smith, Jasper and Clarke counties on a land area less than 1549 acres. Additionally, soybeans 


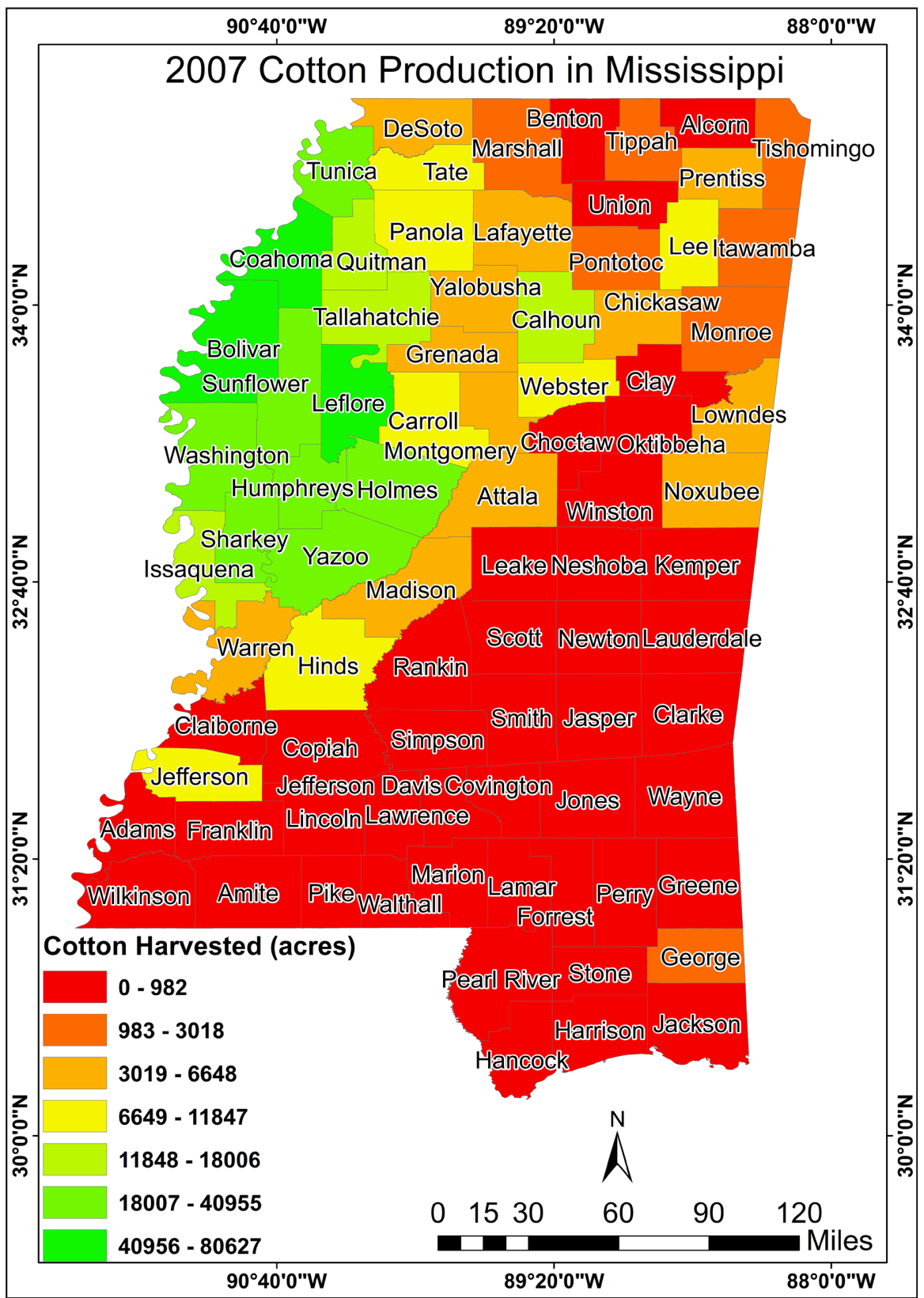

Figure 9. 2007 Cotton production in Mississippi.

were harvested in Adams, Lawrence, Hinds, Rankin, Madison, Carroll Montgomery, Grenada, Lafayette, Clay, Lowndes, Lee Itawamba on one hand and Warren, Noxubee, Calhoun, Chickasaw, Pontotoc, Union, Prentiss, Alcorn, Brenton, Tippah, and Marshall on the other hand with a land area between 1550 and 7771 acres and 7772 and 18,169 acres respectively.

There was a slight change in terms of the harvesting of soybeans in 2018. Majority of the counties in the state, namely, Alcon, Tippah, Lee Itawamba, Yalobusha, Grenada, Clay, Webster, Oktibbeha, Lowndes, Carroll Montgomery, Choctaw, Attala, Winston, Leake, Nescoba, Kemper, Madison, Scott, Newton, Lauderdale, Hinds, Rankin, Smith, Jasper, Clarke, Claiborne, Copiah, Simpson, 


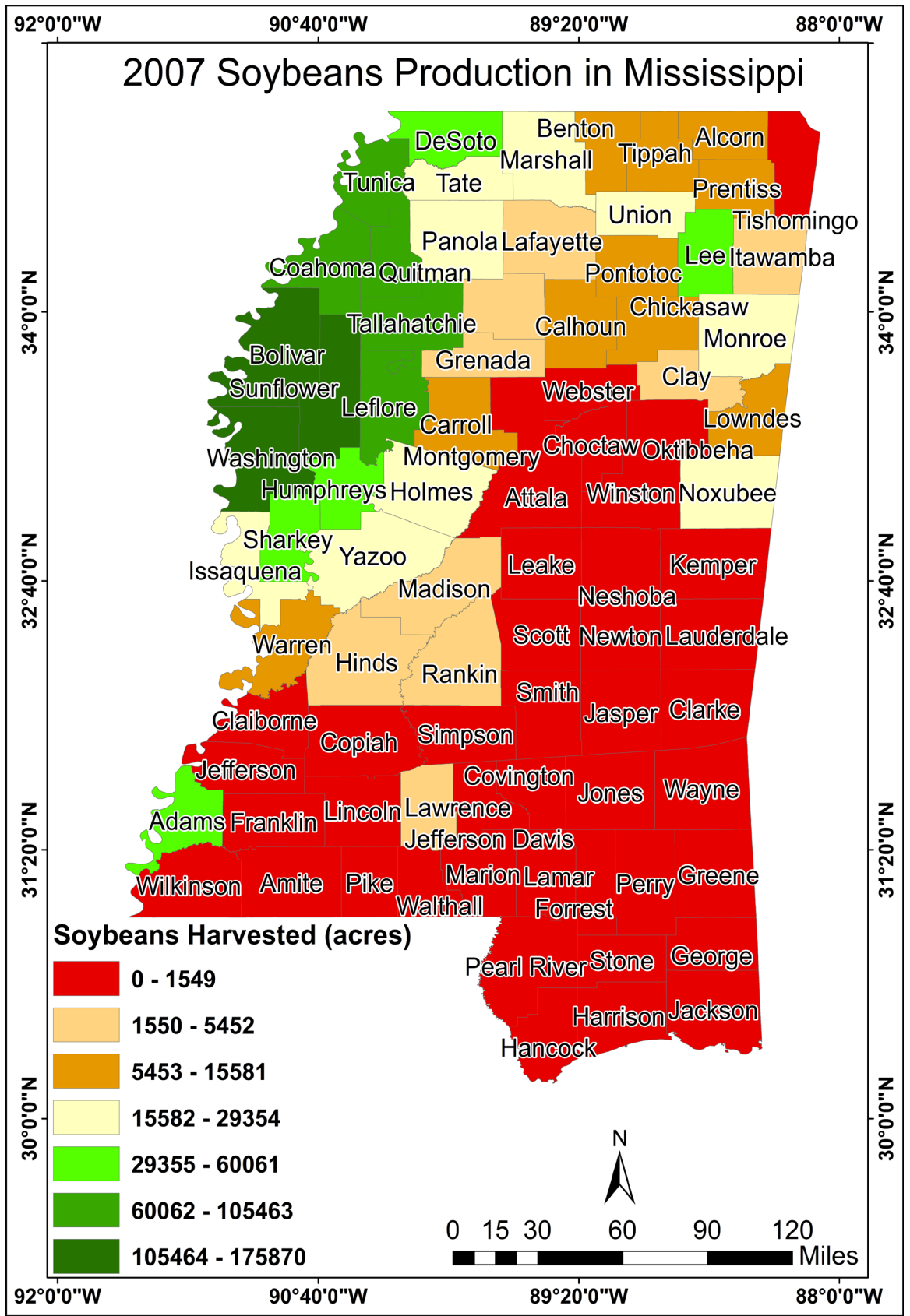

Figure 10. 2007 soybeans production in Mississippi.

Jefferson, Adams, Franklin, Wilkinson, Amite, Pike, Walthall, Lincoln, Lawrence, Jefferson, Davis, Covington, Jones, Wayne, Marion, Larmer Forrest, Perry, Greene, Pearle River, Stone, George, Hancock, Harrison and Jackson used less than 510,000 acres of land for the production of soybeans. Counties which produced soybeans with a relatively larger land areas between 17,200,001 acres and 54,100,000 acres were Bolivar, Sunflower, Washington, and Humphreys. Additionally, Yazoo, Issaquena, Sharkey, Leflore, Tallahatchie, Quitman, Coahoma, and Tunica produced soybeans using between 1,610,001 and 7,280,000 acres of land. 


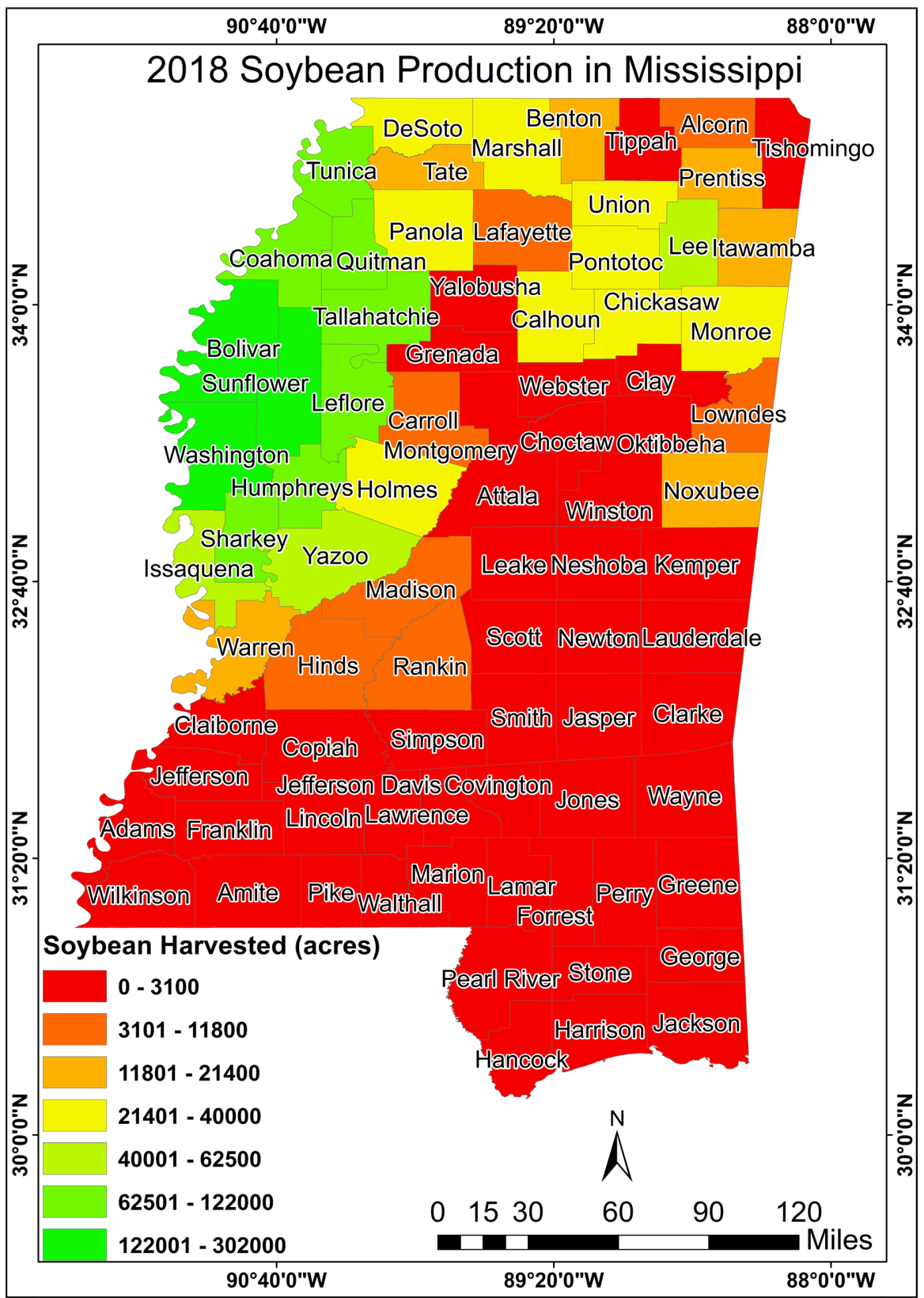

Figure 11. 2018 soybeans production in Mississippi.

\subsection{Wheat Production in Mississippi}

Wheat is basically a small-scale grain produced throughout Mississippi. Wheat commonly delivers up in the line of thirty (30) to fifty (50) bushels per acre whilst yields within the 60-to-80-bushel range may be grown under good management and weather conditions [27].

In 2017, most of the state's wheat was grown on a total land having areas that were between 31,835 and 58,151 acres in the Bolivar County exclusively (Figure 12). Less than 521 acres of land was used in the production of wheat in the Lincoln, Hinds, Copiah, Claiborne, Jefferson, Adams, Franklin, Wilkinson, Brenton, Tishomingo, Prentiss, Union, Lafayette, Chickasaw, Grenada, Clay, Webster, 


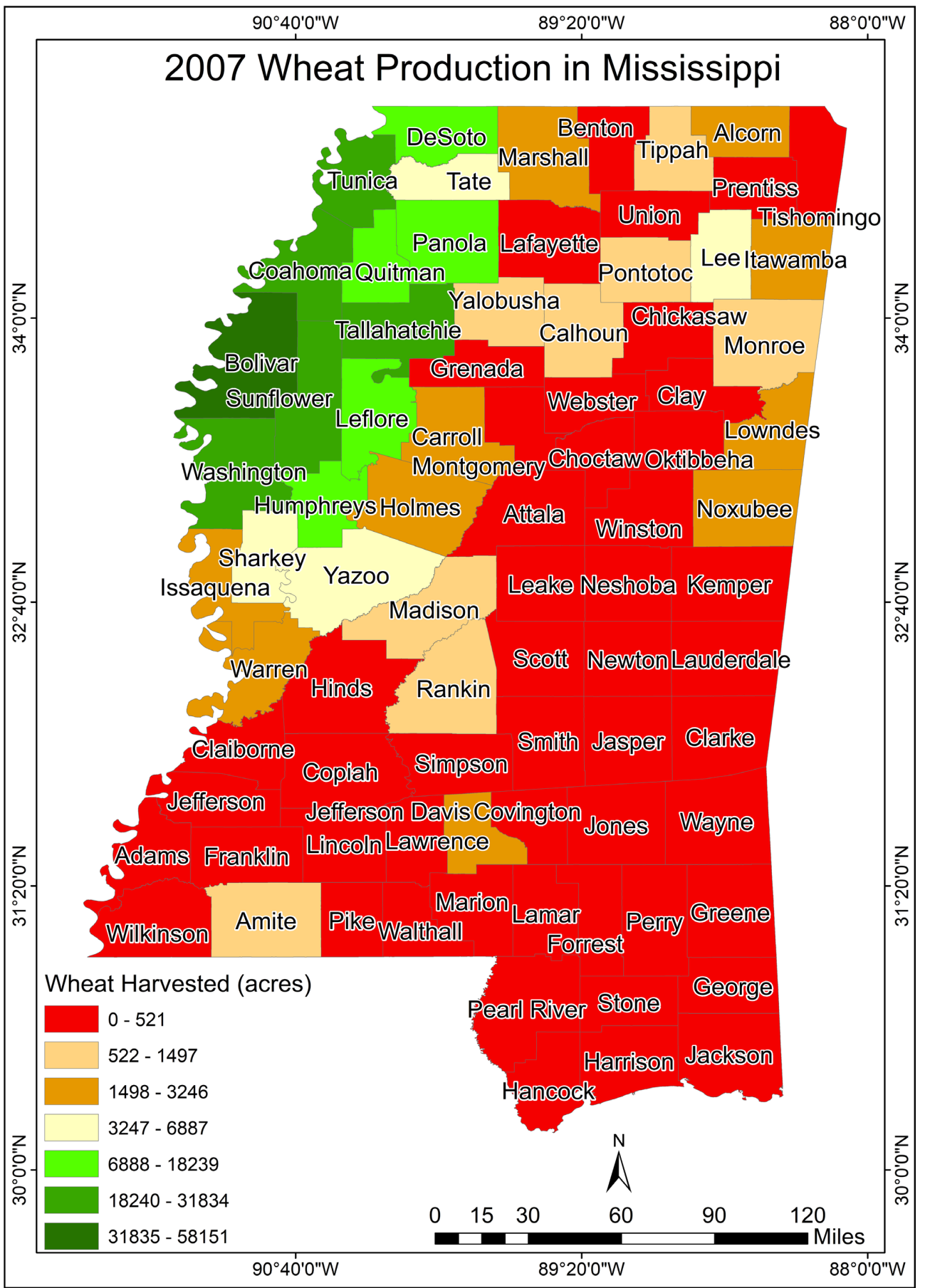

Figure 12. 2007 wheat production in Mississippi.

Choctaw, Oktibbeha, Attala, Winston, Leake, Neshoba, Kemper, Scott, Newton, Lauderdale, Smith, Jasper, Clarke, Simpson, Covington, Jones, Wayne, Davis, Marion, Lamar Forrest, Perry, Greene, Pearl River, Stone, George, Harrison, Hancock, Jackson and Pike counties. Between 6888 and 18,239 acres of land were used in the production of the crop in the Humphreys, Leflore Quitman, and Panola counties. Furthermore, wheat production covered between 522 and 1497 acres of land in the Amite, Waltham, Rankin, Madison, Calhoun, Pontotoc, 
Tippah, and Monroe counties.

\section{Potential Location of Bioenergy Crops: Justification and Conclusions}

The potential area for bio-energy crops is in the MLRA 131 zone. Based on soil properties, geology, climate, water resources, land use and crop output, the 28county Mississippi Delta region represents a contiguous biomass production area covering over 10 million acres (15,624.9 square miles). The region comprises of a broad historic flood plain and its forested perimeter revolves around the Mississippi River. Characterized by common topography, a variety of productive alluvial soil types, it has high levels of surface and groundwater availability, and a favorable climate and comparatively long growing season. The area has a combination of assets that provide significant absolute advantages in the production and development of a strong biomass-based economy which includes the diversity of biomass production such as corn, cotton, soybeans, wheat, rice, barley, grain sorghum, canola, camelina, algae, hardwoods, and softwood (Figures 5-8). Although all the MLRA zones produce the same biomass crop such as corn, cotton, soybean, and wheat, MLRA 131A (Delta Region) has an absolute advantage (ability to produce more of these crops) in the production of these crops (see Figures 5-8) for overall output of these crops.

In summary, the Mississippi Delta region currently produces all the important primary biomass feedstock such as oils (soybeans, canola, camelina, algae), starch (corn, barley, grain sorghum, rice), and sugar (corn, barley, grain sorghum, rice). Opportunities exist to expand on these crops and possibly introduce new crops such as sweet potatoes and sweet sorghum which have similar growing environmental conditions. The paper established that the most produced bioenergy crops in Mississippi State are corn and soybeans. The production of these crops fluctuates through the census years. It has also been established that District 40 and District 10 produce most bioenergy crops in Mississippi, with the former (District 40) being the highest producer. The production at district level indicated that District 40 produced the greatest quantities of corn, cotton, soybeans, and wheat while District 10 produced the greatest quantity of rice. It has also been revealed that rice and cotton production in Mississippi is decreasing over time. To maximize the production of these crops in each district, it is recommended that GIS mapping and land management systems be employed in each agricultural district in Mississippi state to enable researchers and farmers to determine factors that contribute to the increasing and decreasing trends in the production of the bioenergy crops.

\section{Acknowledgements}

This work was supported by the United States Department of Agriculture (USDA) National Institute of Food and Agriculture, McIntire Stennis Project NI21MSCFRXXXG003. Also, we would like to extend our sincere gratitude to 
the Dean of Graduate Studies at Southern University in Baton Rouge, Louisiana, Professor Ashagre Yigletu for providing graduate assistantships to some of the graduate students on this paper in order to promote research and help the students acquire the necessary skill development while earning a graduate degree.

\section{Conflicts of Interest}

The authors declare no conflicts of interest regarding the publication of this paper.

\section{References}

[1] Food and Agriculture Organization (FAO) of the United Nations (2021) Energy. http://www.fao.org/energy/bioenergy/en/

[2] Hill, J., Polansky, S., Nelson, E., Tilman, D., Huo, H., Ludwig, L., Neumann, J., Zheng, H. and Bonta, N. (2009) Climate Change and Health Costs of Air Emissions from Biofuels and Gasoline. Proceedings of the National Academy of Sciences of the United States of America, 106, 2077-2082. https://doi.org/10.1073/pnas.0812835106

[3] International Energy Agency (IEA) (2009) Bioenergy-A Sustainable and Reliable Energy Source. Main Report, IEA Bioenergy ExCo: 2009: 0. International Energy Agency, Paris.

https://www.ieabioenergy.com/wp-content/uploads/2013/10/MAIN-REPORT-Bioe ner-

gy-a-sustainable-and-reliable-energy-source.-A-review-of-status-and-prospects.pdf

[4] Dipti, P. (2013) Bioenergy Crops and Alternate Energy. International Journal of Environmental Engineering and Management, 4, 265-272.

[5] Cushion, E., Whiteman, A. and Dieterle, G. (2010) Bioenergy Development: Issues and Impacts for Poverty and Natural Resource Management. The International Bank for Reconstruction and Development, World Bank, Washington DC.

https://openknowledge.worldbank.org/bitstream/handle/10986/2395/524540PUB0B ioe101Official0Use0Only1.pdf? sequence $=1$ \&isAllowed $=y$

[6] Yadav, P., Priyanka, P., Yadav, K., Kumar, D. and Yadav, A. (2019) Bioenergy Crops: Recent Advances and Future Outlook. In: Rastegari, A., Yadav, A. and Gupta, A., Eds., Prospects of Renewable Bioprocessing in Future Energy Systems, Springer, Cham, 315-335. https://doi.org/10.1007/978-3-030-14463-0_12

[7] Kim, S. and Dale, B.E. (2011) Indirect Landuse Change for Biofuels: Testing Predictions and Improving Analytical Methodologies. Biomass and Bioenergy, 35, 3235-3240. https://doi.org/10.1016/j.biombioe.2011.04.039

[8] Yall Politics Staff (2012) Governor Phil Bryant on Mississippi's New Energy Proposal. Yall Politics.

https://yallpolitics.com/index.php/yp/post/governor_phil_bryant_on_mississippis_ new_energy_proposal/

[9] Mitchell, C. (2012, March 18). When It Comes to Energy, Governor Is Pro-Diversity. The Vicksburg Post.

https://www.vicksburgpost.com/2012/03/18/when-it-comes-to-energy-governor-ispro-diversity/

[10] Karp, A. and Shield, I. (2008). Bioenergy from Plants and the Sustainable Yield Challenge. New Phytologist, 179, 15-32.

https://doi.org/10.1111/j.1469-8137.2008.02432.x 
[11] Hejazi, M., Voisin, N., Liu, L., Braman, L., Fortin, D., Hathaway, J., Huang, M., Kyle, P., Leung, R., Li, H., Liu, Y., Patel, P., Pulsipher, T., Rice, J., Tesfa, T., Vernon, C. and Zhou, Y. (2015) Twenty-First Century United States Emissions Mitigation Could Increase Water Stress More than the Climate Change it is Mitigating. Proceedings of National Academy of Sciences of the United States of America, 112, 10635-10640. https://doi.org/10.1073/pnas.1421675112

[12] Guo, T., Raj, C., Chaubey, I., Gitau, M., Arnold, J., Srinivasan, R., Kiniry, J. and Engel, B. (2018) Evaluation of Bioenergy Crop Growth and the Impacts of Bioenergy Crops on Streamflow, Tile Drain Flow and Nutrient Losses in an Extensively TileDrained Watershed Using SWAT. Science of the Total Environment, 613-614, 724-735. https://doi.org/10.1016/j.scitotenv.2017.09.148

[13] Gelfand, I., Sahajpal, R. and Zhang, X. (2013) Sustainable Bioenergy Production from Marginal Lands in the US Midwest. Nature, 493, 514-517.

https://doi.org/10.1038/nature11811

[14] Lewis, S.M. and Kelly, M. (2014) Mapping the Potential for Biofuel Production on Marginal Lands: Differences in Definitions, Data and Models across Scales. ISPRS International Journal of GeoInformation, 3, 430-459.

https://doi.org/10.3390/ijgi3020430

[15] USDA-Natural Resources Conservation Service-Soils (2020) MLRAs in MO-7. https://www.nrcs.usda.gov/wps/portal/nrcs/detail/soils/survey/office/ssr7/tr/?cid=n rcs142p2_048051

[16] USDA-Natural Resources Conservation Service (2006) Land Resource Regions and Major Land Resource Areas of the United States, the Caribbean, and the Pacific Basin. No. 296, United States Department of Agriculture, Washington DC. https://www.nrcs.usda.gov/Internet/FSE_DOCUMENTS/nrcs142p2_051845.pdf

[17] USDA-Natural Resources Conservation Service, Mississippi (2020) Soils. https://www.nrcs.usda.gov/wps/portal/nrcs/detail/ms/soils/?cid=nrcs142p2_017215

[18] USDA-National Agricultural Statistics Service (NASS) (1987) Census of Agriculture. Part 24. Mississippi State and County Data: Vol. 1, Geographic Area Series. http://lib-usda-05.serverfarm.cornell.edu/usda/AgCensusImages/1987/01/24/1987-0 1-24.pdf

[19] USDA-National Agricultural Statistics Service (NASS) (1997) Census of Agriculture. Mississippi State and County Data.

http://agcensus.mannlib.cornell.edu/AgCensus/getVolumeOnePart.do?year=1997\& part_id=922\&number=24\&title=Mississippi

[20] USDA-National Agricultural Statistics Service (NASS) (2007) Census of Agriculture. Mississippi State and County Data. Vol. 1, Geographic Area Series, Part 24.

https://www.nass.usda.gov/Publications/AgCensus/2007/Full_Report/Volume_1,_C hapter_1_State_Level/Mississippi/msv1.pdf

[21] USDA-National Agricultural Statistics Service (NASS) (2017) Census of Agriculture. Mississippi State and County Data. Vol. 1, Part 24. United States Department of Agriculture, Washington DC.

https://www.nass.usda.gov/Publications/AgCensus/2017/Full_Report/Volume_1,_C hapter_1_State_Level/Mississippi/msv1.pdf

[22] The United States Department of Agriculture (USDA) (1992) Weights, Measures, and Conversion Factors for Agricultural Commodities and Their Products. USDA Economic Research Service in Cooperation with the Agricultural Marketing Service, the Agricultural Research Service, and the National Agricultural Statistics Service, U.S. Department of Agriculture. Agricultural Handbook No. 697. United States De- 
partment of Agriculture, Washington DC.

https://www.ers.usda.gov/webdocs/publications/41880/33132_ah697_002.pdf

[23] Namwamba, J., Twumasi, Y., Okwemba, R., Osimbo, B., Akinrinwoye, C., Oppong, J. and Olwochi, S. (2021) Applying the Normal Distribution Generator to Determine Tolerance Spans of Modeled Death Rates of Developed Countries. The 95th Annual Meeting of the Louisiana Academy of Sciences, Online Hosting by Louisiana Tech University, 13 March 2021, 12.

[24] Mississippi Encyclopedia (2017) Corn in Washington County: Dorothea Lange. Library of Congress, Washington DC.

[25] Mississippi State University Extension (2021) Cotton. http://extension.msstate.edu/agriculture/crops/cotton

[26] Coblentz, B. (2019) Mississippi Cotton: Late Season, Heat, Dry Weather Aided State Crop. Mississippi Market Bulletin, 91, 2.

https://agnet.mdac.ms.gov/mmbfirstlook/ArchiveView?201910181324321551MMB. PDF

[27] Mississippi Agricultural Consultants Association (2021) Wheat. https://www.msagconsultants.com/?page_id=104 